\title{
Ergonomic Evaluation of Three Types of Inner-Room Floor Mats by Using In-Shoe and Platform Type Pressure Measurement Systems
}

\author{
Seokhee $\mathrm{NA}^{1}$, Min Keun CHUNG ${ }^{1}$ and Young-Woong SoNG ${ }^{2 *}$ \\ ${ }^{I}$ Department of Industrial and Management Engineering, Pohang University of Science and \\ Technology, Pohang, 790-784, South Korea \\ ${ }^{2}$ Department of Occupational Health, Catholic University of Daegu, Hayang Gyeongbuk, 712- \\ 702, South Korea
}

\begin{abstract}
Prolonged work in upright postures (standing and walking) is common in industry and in daily living activities, and is one possible risk factor for low back pain and leg problems. This study compared the reaction forces of four different floor surface conditions (three inner-room floor mats and no-mat) during gait. The reaction forces were measured by both the in-shoe and platform type pressure measurement systems. Six male subjects (average weight $=72.4 \pm 7.5 \mathrm{~kg}$ ) walked barefoot on the four floor conditions and the data from the two measurement systems were recorded simultaneously. The mean reaction force, two peak forces (heel strike and toe off), and the maximum reaction force measured by the in-shoe type system showed significantly different values according to the floor surface conditions $(P<0.05)$. The no-mat condition induced the largest mean reaction force of $828.9 \pm 114.2$ $\mathrm{N}$, However there was no difference in the reaction forces measured from the platform type system $(P>0.05)$. All three floor mats induced smaller reaction forces than no-mat, but the mean reaction force and maximum reaction forces (maximum and two peak forces) showed different results due to different thickness and materials. Thus, an appropriate selection of inner-room floor mat according to the biomechanical properties may be useful for reduction of fatigue and discomfort in industrial settings.
\end{abstract}

Key words : foot pressure, reaction force, gait, floor mat, floor surface condition.

(Received 23 July 2010, accepted 3 December 2010) 


\section{Introduction}

Prolonged work in upright postures (standing and walking) is common in industry and in daily living activities, and is one possible risk factor for low back pain and leg problems $[1,2]$. Health problems associated with prolonged standing and walking include lower extremity discomfort and fatigue, lower extremity swelling and venous blood pooling, low back pain and entire body fatigue [3].

Soft floor surface mats are used to reduce fatigue during prolonged standing and walking in many situations. Much research has tried to find out the influence of various floor mats on fatigue and discomfort. According to a literature review paper by Rys and Konz [4], floor surface mats are able to diminish discomfort associated with prolonged standing work. Also, the benefits of using floor mats can include reduced fatigue, enhanced balance, and the potential for reduced back and leg disorders, especially when employees spend a considerable amount of time on their feet $[3,5,6]$.

In a series of research, Rys and Konz [7, 8] and Konz et al. [9] compared concrete and industrial carpet or mats using physiological criteria (foot volume, skin temperature and heart rate) and subjective rating. They found that body comfort decreased on all body parts with time, but the decreasing level was different according to the body parts. It was also found that carpet or mats were more comfortable than concrete. Similar results were also found in other studies $[5,6$, 10]. These studies focused on physiological responses or subjective feelings induced by different floor conditions.

However, mechanical properties such as shock absorption or plantar pressure distribution can give a useful and quantitative indication of the profound effects of floor mats on fatigue and discomfort. Ground reaction forces or plantar pressure distribution are used widely in gait analysis and in the evaluation of various floor mats or shoes $[1,11]$. There are two types of pressure measuring systems: one uses platform type sensors, the other uses in-shoe type sensors. Platform type sensors are located below the floor mats, while in-shoe type sensors are located between the mats and the foot. Barnett et al. [12] compared the in-shoe type system with a force platform. In most cases, comparisons of the data recorded by the two systems provided good evidence for the accuracy and reliability of temporal measurements.

Most previous studies investigated the influence of the floor mats in industrial settings where subjects wore shoes and industrial mats were used. However, ergonomic evaluation of floor mats in inner-room setting is also important, particularly in Korea and in some other Asian countries. Korean people usually spend much time without shoes in rooms covered with inner-room mats. According to the Korean Women's Development Institute[13], Korean housewives spend about 7 hours a day at home without shoes. Also, in traditional Korean restaurants or other small-size companies such as the sewing industry, people work on floor mats without shoes.

The objective of this study was 1) to investigate the effects of the different floor mats for inner room (without shoes) on the reaction forces, and 2) to compare the different measures (mean reaction forces and peak reaction forces, et al.) in evaluating the floor mats by using the in-shoe and platform type pressure measurement systems. 


\section{Materials and Methods}

Six male subjects participated in the experiments. Their mean age, height, weight and barefoot size were $23 \pm 3$ years, $174.8 \pm 4 \mathrm{~cm}, 72.4 \pm 7.5 \mathrm{~kg}$ and $273 \pm 6.8 \mathrm{~mm}$, respectively. None of the subjects reported a history of foot or ankle musculoskeletal/neuromuscular trauma or disease.

The subjects walked barefoot on each floor surface condition 5 times, and the sequence was fully randomized. The subjects chose their own walking speeds and step widths. There were four floor surface conditions. First, 'E' was the baseline condition with no mat. 'A' was a $2 \mathrm{~mm}$ thick normal polyvinyl chloride (PVC) mat used in inner rooms. 'B' was a $6.5 \mathrm{~mm}$ thick mat used in offices or in trains with shoes. ' $C$ ' was a $4 \mathrm{~mm}$ thick cushion mat, which has been recently developed to be used barefoot in inner rooms. The three mats were products of one chemical company in Korea and had different thickness, materials and other physical characteristics (unrevealed outside the company).

The subjects walked on the gait way about $5 \mathrm{~m}$ (Fig. 1) with an in-shoe type pressure sensor system (Pedar, Novel Co., Germany) inside their socks. Pedar is a pressure measuring device, composed of $2.6 \mathrm{~mm}$ thick insoles, containing a force sensing matrix of 99 capacitance sensors, with a spatial resolution of approximately $10 \mathrm{~mm}$. In the gait way, there was a platform type pressure measuring device (Emed, Novel Co., Germany) installed beneath the gait-way surface. The Emed system contains $38 \times 72$ force sensing matrix. The data were collected simultaneously from the Emed and Pedar systems, with a sampling frequency of $50 \mathrm{~Hz}$ on the right foot.
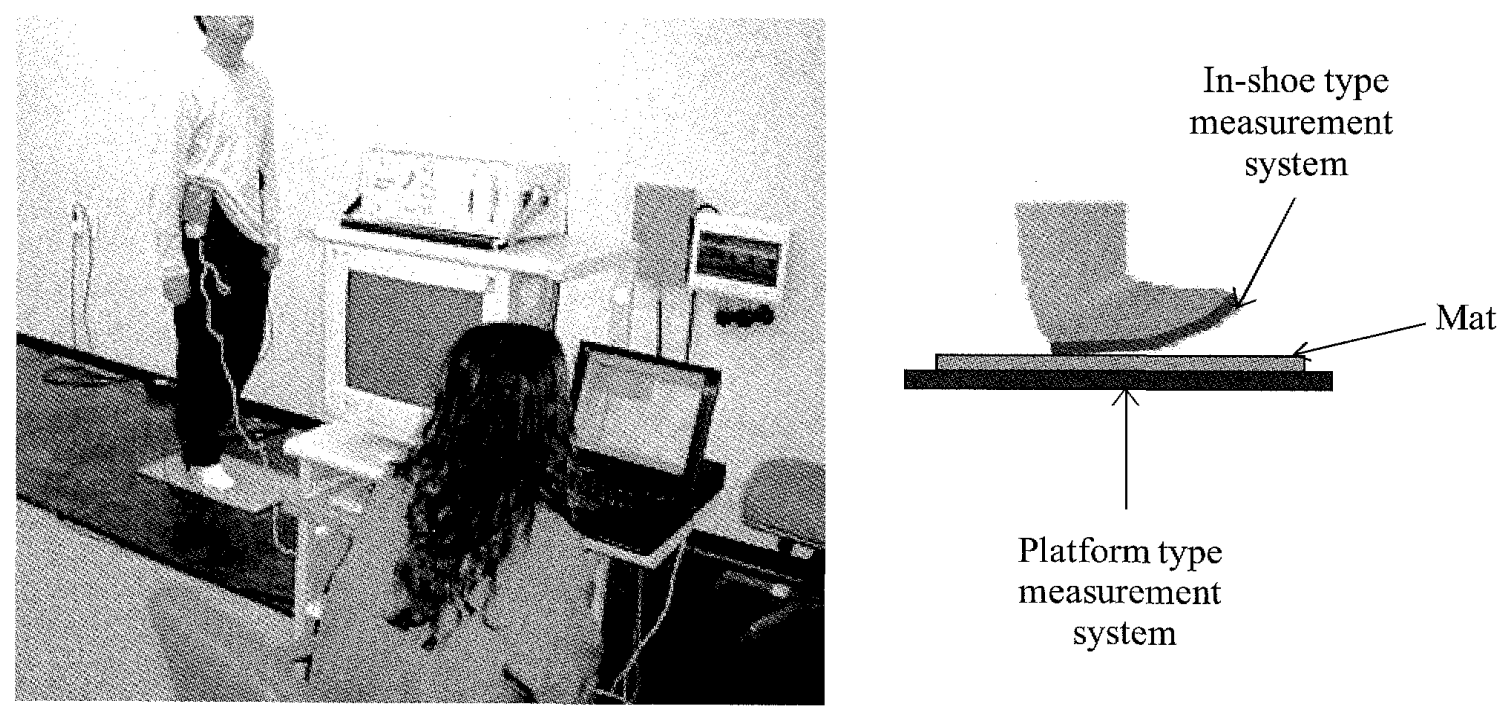

Platform type measurement system

Fig. 1. The layout of experimental setup. 
Four dependent variables were mean reaction force, two peak forces (heel-strike and toe-off), and maximum reaction forces. All reaction forces were summed up during foot contact and the mean reaction forces were calculated by dividing the sum by the time of foot contact. One-way analysis of variance (ANOVA) procedures were conducted on the four reaction forces to evaluate the effect of the floor surface conditions on the reaction forces. The independent variable was the floor surface condition (four levels) with five repetitions in each subject. The average value of the five repetitions in each condition was used in the analysis. Also, further post hoc SNK (Student Newman-Keuls) comparison tests $(\alpha=0.05)$ were conducted to see the difference among the floor surface conditions.

\section{Results}

\section{Temporal gait pattern}

One example of the reaction force profile obtained from the platform type and in-shoe type is presented in Fig. 2. The first peak is induced during heel contact, and the second peak corresponds to the plantar extension (toe off). In Fig. 2, the first peak forces showed higher values than the second peaks, but the magnitude order of the two peak forces was not consistent throughout the subjects, and the mat conditions.

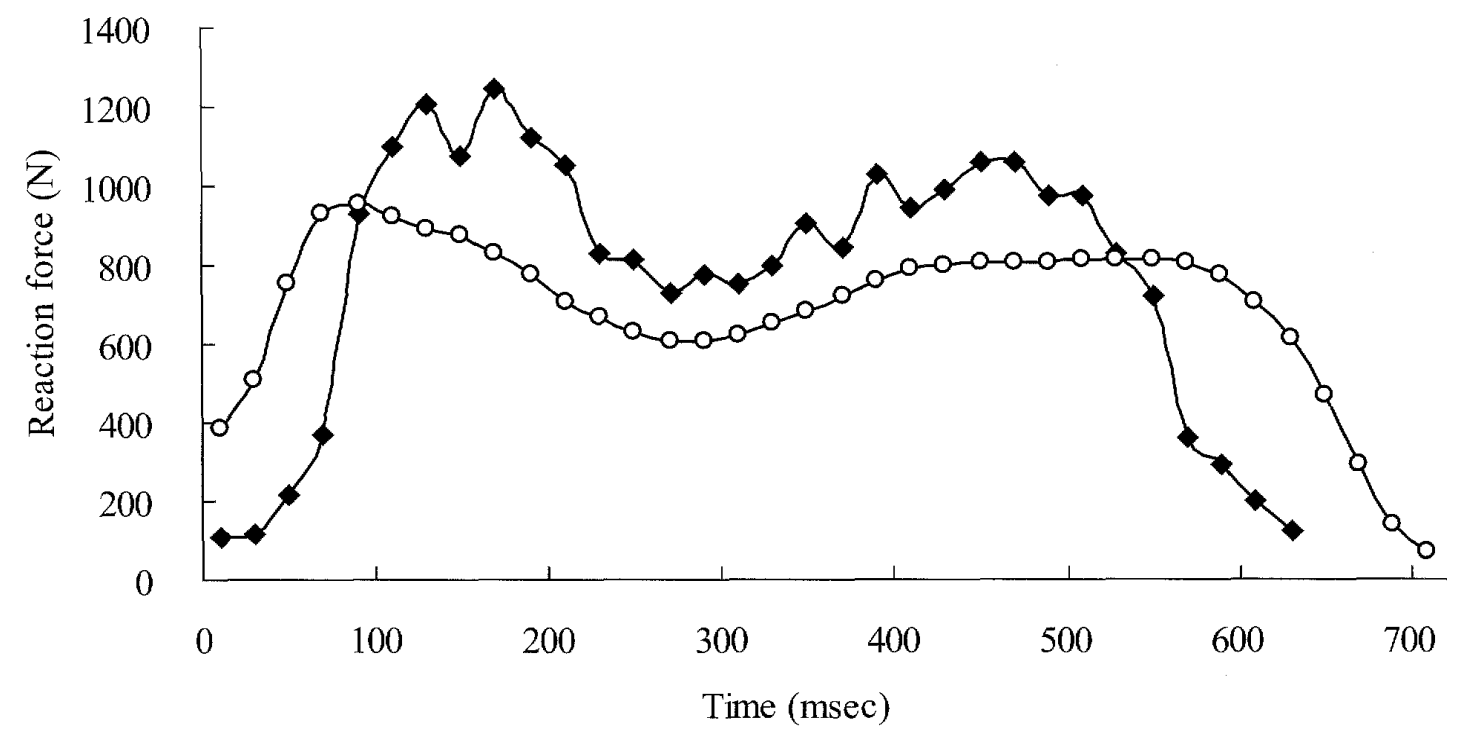

Fig. 2. One example of reaction force profiles collected by the in-shoe and platform type measurement systems. $\bullet$ : in-shoe type, o: platform type.

\section{Foot contact time}

Table 1 shows the times of foot contacts. The in-shoe type measurement system showed shorter contact times (mean difference $=0.04 \mathrm{sec}$ ) than the platform type. However, there was little time difference among the four floor surfaces. 
Table 1. Foot contact times (mean \pm S.D.) of the two measurement types (sec)

\begin{tabular}{lcc}
\hline Floor surface condition & Platform type & In-shoe type \\
\hline E & $0.76 \pm 0.04$ & $0.71 \pm 0.07$ \\
A & $0.75 \pm 0.04$ & $0.71 \pm 0.07$ \\
B & $0.76 \pm 0.04$ & $0.72 \pm 0.07$ \\
C & $0.76 \pm 0.05$ & $0.72 \pm 0.07$ \\
\hline
\end{tabular}

\section{Mean reaction forces}

The effect of the floor surface condition on the mean reaction force (in-shoe type) was found to be statistically significant $(P<0.001)$ from ANOVA procedure (Table 2$)$, but the effect was not statistically significant for the platform type $(P=0.18)$.

Table 2. ANOVA results of mean reaction forces

\begin{tabular}{lccccc}
\hline Source & DF & SS & MS & F-value & $P$-value \\
\hline FSC & 3 & 195591 & 65197 & 82.18 & $<0.001$ \\
Sub & 5 & 240396 & 48079 &. &. \\
FSC $\times$ Sub & 15 & 11900 & 793 &. &. \\
\hline
\end{tabular}

FSC: Floor surface condition, Sub: Subject

The mean reaction forces of the four surface conditions are shown in Fig. 3. The SNK (Student Newman-Keuls) comparison test $(\alpha=0.05)$ for the mean reaction forces of the in-shoe type revealed significant differences among the floor surface conditions (three groups: G1, G2 and G3). The mean reaction forces of the no mat (' $E$ ') condition showed the highest value of $828.9 \pm 114.2$ $\mathrm{N}$ (group 1), and the mean reaction forces of the 'A' and 'B' mats were $715.5 \pm 115.1 \mathrm{~N}$ and 697.9 $\pm 90.1 \mathrm{~N}$, respectively, and grouped together (group 2). The ' $\mathrm{C}$ ' mat induced the lowest reaction force of $619.9 \pm 101.7 \mathrm{~N}$ (group 3).

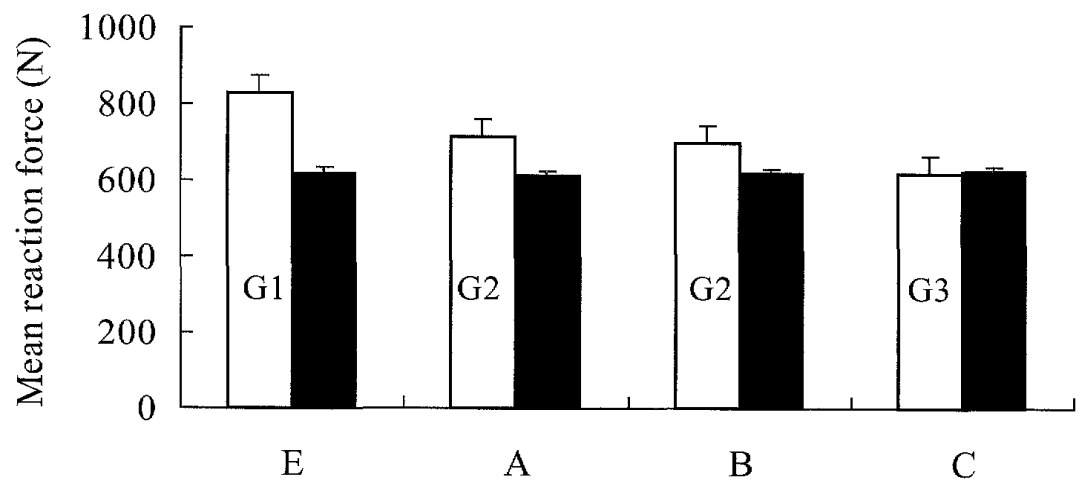

Floor surface condition

Fig. 3. Mean reaction forces (mean \pm S.E.) of the different floor surface conditions. $\square$ : in-shoe type, $\mathbf{\square}$ : platform type. Student Newman-Keuls (SNK) test $(\alpha=0.05)$ grouped the four floor surface conditions into three different groups (G1, G2, and G3) for the in-shoe type. 
First (heel strike) and second (toe off) peak forces

The first and second peak forces measured from the in-shoe type showed statistically different values in different floor conditions $(P<0.001$ from ANOVA test). Figure 4 shows the first and second peak forces of the in-shoe type with the results of the SNK test. The SNK grouping results in the first and second peak forces were different from those of the mean reaction forces. The no mat ('E') condition revealed the highest peak forces (first peak force: $1320.7 \pm 145.6 \mathrm{~N}$, second : $1348.7 \pm 234.4 \mathrm{~N}$, group 1) and the 'A' mat revealed the mean peak values of $1064.4 \pm$ $250.8 \mathrm{~N}$ for the first peak and $1081.2 \pm 150.8 \mathrm{~N}$ for the second peak (group 2). The ' $\mathrm{B}$ ' and ' $\mathrm{C}$ ' mats showed low peak forces (first peak force : $893.9 \pm 167.6 \mathrm{~N}$ for the ' $\mathrm{C}$ ' and $844.3 \pm 172.8 \mathrm{~N}$ for the 'D', second : $909.3 \pm 125.0 \mathrm{~N}$ for the ' $\mathrm{C}$ ' and $905.6 \pm 115.1 \mathrm{~N}$ for the ' $\mathrm{D}$ ') and grouped together (group 3).

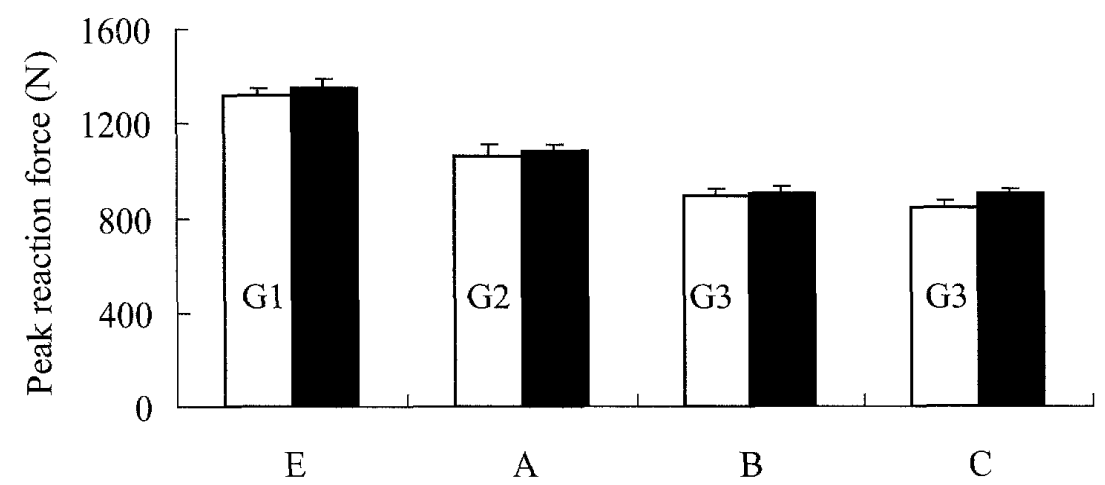

Floor surface condition

Fig. 4. The first and second peak reaction forces (mean \pm S.E.) of the in-shoe type according to the different floor surface conditions. $\square$ : first peak force (heel strike), $\square$ : second peak force (toe off). Student Newman-Keuls (SNK) comparison test grouped the four floor surface conditions into three different groups (G1, G2, and G3).

However, the platform type didn't show different peak forces according to the four floor conditions ( $P=0.79$ for the first peak and $P=0.43$ for the second peak, respectively) as shown in Fig. 5 .

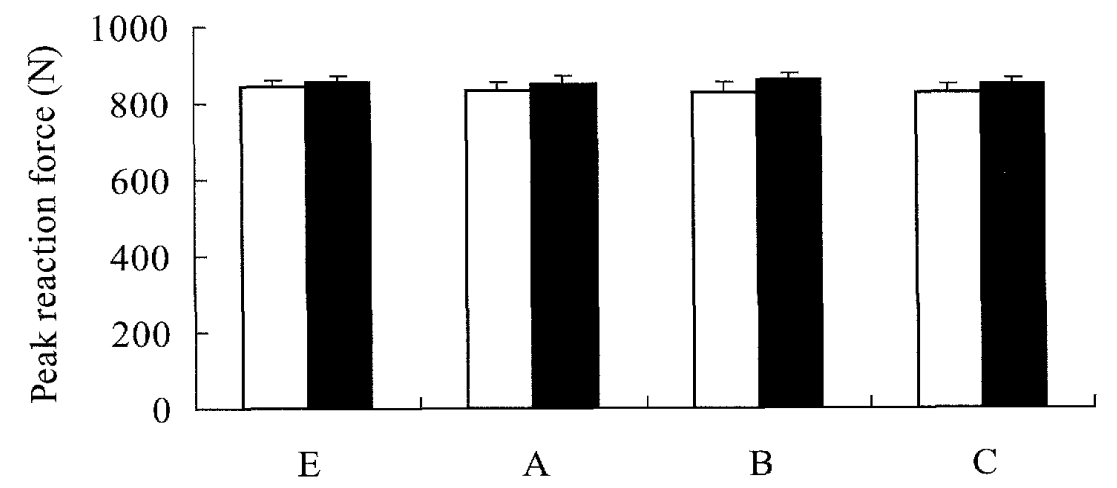

Floor surface condition

Fig. 5. The first and second peak reaction forces (mean \pm S.E.) of the platform type according to the different floor surface conditions. $\square$ : first peak force (heel strike), $\mathbf{\square}$ : second peak force (toe off). 


\section{Maximum reaction force}

The maximum reaction forces during the foot contact were also analyzed and the results were the same as those of the two peak forces. The effect of the floor surface condition on the maximum reaction forces measured by the platform type was not statistically significant $(P=0.42)$, but the mat effect showed a statistically significant effect on the maximum reaction forces for the in-shoe type $(P<0.001)$. The maximum reaction force (in-shoe type) of the no mat ( $\mathrm{E}$ ') condition showed the highest value of $1469.9 \pm 145.4 \mathrm{~N}$ (group 1), and the 'A' mat revealed 1179.8 $\pm 141.2 \mathrm{~N}$ (group 2). The 'B' and 'C' mats induced low values of $961.0 \pm 130.7 \mathrm{~N}$ and $928.8 \pm$ $106.1 \mathrm{~N}$, respectively (group 3 ).

Because reaction forces can be highly correlated with the subject's weight, we normalized the reaction forces by subject weights. However, the results showed the same trend.

\section{Discussion}

In this study, reaction forces of four floor surface conditions during gait were compared using both the platform and in-shoe type pressure measurement systems. The reaction forces of the three mats were smaller than the no mat condition when measured by the in-shoe type measurement system. Thus, the three mats can diminish the biomechanical load on the various joints and muscles, and this could help reduce fatigue during gait.

The foot contact times of the in-shoe type were shorter than those of the platform type. The two systems used the same sampling frequency of $50 \mathrm{~Hz}$ (one sample at every $20 \mathrm{~ms}$ ), so this time difference might be caused by the different attachment configuration of the sensors. The sensors of the platform type were arranged parallel on a flat panel, but those of the in-shoe type were placed along the curvature of the foot. Thus, the in-shoe type detected the heel strike later and detected the toe off earlier than the platform type. This different attachment configuration might also affect the sensitivity of the two measurement systems.

The reaction forces measured by the platform type were not affected by the floor surface conditions $(P>0.05)$, but the reaction forces measured by the in-shoe type showed different values according to the floor surface conditions $(P<0.05)$. This result indicates that in-shoe type is more sensitive than platform type in evaluating the reaction force induced by inner-room floor mats. The reason might be attributable to the different placement of sensors in addition to the sensor attachment difference, as discussed earlier. While platform sensors are placed under the floor surface, in-shoe sensors are placed between the foot and floor surface. Because of this difference, the platform type can not detect minute differences of the floor surface condition.

When the reaction force was evaluated using the in-shoe type measurement system, the floor surface condition had a significant effect on the mean reaction forces, first (heel strike) and second (toe off) peak forces and maximum reaction forces. The four dependent variables showed a similar trend except 'B' mat. The 'B' mat produced relatively high mean reaction force but relatively low peak values (maximum reaction force and two peak forces). This might be due to the property of ' $\mathrm{B}$ ' mat. ' $\mathrm{B}$ ' mat is usually used in an office or train, and is relatively thick and hard. Thus, 'B' may have absorbed higher forces rather than lower forces. Therefore, both the mean 
reaction force and maximum reaction forces (maximum or the two peak forces) need to be analyzed to evaluate floor mats' properties.

In this study, mean, two peak forces, and maximum reaction forces were used to evaluate four floor surface conditions. Other measures could also be used to evaluate floor surfaces. Barnett et al. [12] compared temporal parameters (e.g., first peak force, mid peak low, second peak force, duration, peak to peak, impulse), which were obtained from both a force measuring platform (Kistler) and a pressure measuring system (Pedar). Therefore, further research needs to be performed to evaluate floor surface conditions using the temporal parameters obtained from inshoe and platform types.

The subjects who participated in this study were all male students. However, there can be gender or racial differences in gait pattern [14], so that the effect of different gait pattern caused by different gender, race, or pregnancy should be investigated further.

\section{Conclusions}

This research compared four floor conditions (no-mat and three inner-room floor mats) using reaction forces measured from both the in-shoe and platform type pressure measurement systems. The conclusions of this research can be summarized as follows.

1) Floor mats induced smaller reaction forces (mean, two peak forces, and maximum reaction forces) than the hard floor (no mat) condition.

2) The mean, maximum reaction force, and two peak forces measured by the in-shoe type pressure measurement system were sensitive enough to differentiate inner-room floor mats, but the platform type used in this study was not sensitive in evaluating inner-room floor mats.

3) The mean reaction force and three maximum reaction forces (maximum and two peak forces) showed different results in SNK comparison tests. Thus, these measures should be considered together in evaluating inner-room floor mats.

\section{References}

1. Hansen L, Winkel J \& Jørgensen K (1998) : Significance of mat and shoe softness during prolonged work in upright position: Based on measurements of low back muscle EMG, foot volume changes, discomfort and ground force reactions. Appl Ergon 29: 217-224

2. Ryan GA (1989) : The prevalence of musculo-skeletal symptoms in supermarkets workers. Ergonomics 32: 359-371

3. Chester MR, Rys MJ \& Konz SA (2002) : Leg swelling, comfort and fatigue when sitting, standing, and sit/standing. International Journal of Industrial Ergonomics 29: 289-296

4. Rys M \& Konz S (1994) : Standing. Ergonomics 37: 676-687

5. Cham R \& Redfern MS (2001) : Effect of flooring on standing comfort and fatigue. Hum Factors 43 : 381-391

6. Kim JY, Stuart-Buttle C \& Marras WS (1994) : The effects of mats on back and leg fatigue. Appl Ergon 25: 29-34 
7. Rys M \& Konz S (1988) : Standing work: carpet vs concrete. Proceedings of the Human Factors Society 32nd Annual Meeting: 522-526

8. Rys M \& Konz S (1989) : An evaluation of floor surfaces. Proceedings of the Human Factors Society 33rd Annual Meeting: 517-520

9. Konz S, Bandla V, Rys M \& Samabasivan J (1990) : Standing on concrete vs floor mats. In: Advances in Industrial Ergonomics and Safety II. (Das B, ed). Taylor \& Francis, London pp 991-998

10. Redfern MS \& Chaffin DB (1988): The effects of floor types on standing tolerance in industry. In: Trends in Ergonomics/Human Factors V. (Aghazadeh F, ed). Elsevier, North-Holland pp 401-405

11. Light LH, McLellan GE \& Klenerman L (1980) : Skeletal transients on heel strike in normal walking with different footwear. J Biomech 13: 477-480

12. Barnett S, Cunningham JL \& West S (2001) : A comparison of vertical force and temporal parameters produced by an in-shoe pressure measuring system and a force platform. Clin Biomech 16: 353-357

13. Korean Women's Development Institute (2003) : Survey of Korean women's distribution of time use. http://www.kwdi.re.kr

14. McKean KA, Landry SC, Hubley-Kozey CL, Dunbar MJ, Stanish WD \& Deluzio KJ (2007) : Gender differences exist in osteoarthritic gait. Clin Biomech 22: 400-409 
靴内装着型および固定型足底圧計測システムを用いた 3 種類の室内フロアマット の人間工学的評価

\section{ナ スクピ1,チョン ミンクン1 ,ソン ヨンウン²}

1 浦項工科大学 $(\mathrm{POSTECH})$ 産業経営工学科

2大邱カトリック大学 産業保健学科

要旨：立位姿勢(直立ないし歩行)での長時間の作業は, 就業時や日常の活動においても普 通にあり，腰痛や下肢障害の危険因子の一つである，本研究では異なる4 種類の床面状態 ( 3 種類 のフロアマットとフロアマットなし) で歩行時の床反力の比較を行った，床反力は靴内装着型拉 よび固定型足底圧計測システムの雨者によって測定した．6名の男性被験者 (平均体重 $=72.4 \pm 7.5$ $\mathrm{kg}$ ) は4種類の状態の床を裸足で歩行し，2種の測定システムで足底圧を同時に記録した，平均床反 力, 2 つの極大值(踵接地㧍よび足趾離床)，㧍よび靴内装着型足底圧計測システムにより測定され た最大床反力は床表面状態により有意に異なる測定值を示し $(P<0.05)$, 床材がない場合が $828.9 \pm$ $114.2 \mathrm{~N}$ で最大の床反力であった。しかしながら, 固定型足底圧計測システムによる測定では有意 な差は得られなかった。フロアマットがない場合と比較すると 3 種のフロアマットすべてが床反

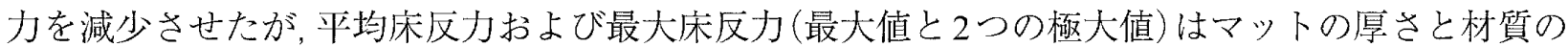
違いにより違いがあった。以上のことから, バイオメカニカルな特性に従った適切なフロアマッ 卜の選択を行うことが作業時での疲労と不快感の減少に有効であると考えら机る.

キーワード：足底圧, 床反力, 歩行, フロアマット, 床表面状態.

J UOEH (産業医大誌) 33(1)：1-10(2011) 